\title{
The biggest cost of the COVID-19 virus in China could be freedom
}

Edition 1, 2020

Associate Professor Delia Lin

DOI: 10.37839/MAR2652-550X1.3

The Chinese Communist Party (CCP) leadership is referring to the battle against the coronavirus disease (COVID-19) in military terminology as a 'counter-offensive' (zuji zhan) and 'the war of the people' (renmin zhanzheng).

'Conflict readiness' (beizhan) and 'a sense of crisis' (weiji gan) may be in the genes of the CCP as a revolutionary Party, and the current militaristic rhetoric legitimates and justifies excessive social control measures that are likely to remain in place after the COVID-19 crisis is over. The rhetoric of war has placed the highest priority on order and obedience and enabled the CCP to upgrade its control over the Chinese people.

Although the first patient with COVID-19 was identified as early as 1 December 2019 , the general public was unaware of the severity and spread of the potentially deadly disease until the lockdown of Wuhan by the Government on 23 January, a city of more than 11-million in Hubei province. Large-scale quarantine efforts such as this are unprecedented in modern history. Less than three weeks later, a strict curfew (fengbi shi guanli) was imposed upon every suburb across the entire Hubei Province with a population greater than 58 million. Around the same time, over 80 cities across China were in lockdown.

In retrospect, from December to 23 January, Wuhan was fighting battles on two fronts: a public one and a covert one. The public battle saw a series of events showcasing the achievements of Wuhan as a dazzling star in the eyes of the CCP. On 3 December 2019, at the national conference on modernisation of social governance 
at the municipal level held in Beijing, Wuhan was the only provincial capital selected to speak to the conference. Wuhan experience - known as 'led by red' (hongse yinling) - was warmly praised and encouraged as the model to be adopted across the entire nation. Five weeks on, from 7-17 January 2020, the Hubei and Wuhan lianghui, annual plenary sessions of the local People's Congress and the local committee of the Chinese People's Political Consultative Conference, were held and celebrated as planned. Behind all this glamour, medical professionals and scientists were covertly battling the spread of a new deadly virus, directed not to discuss it on any public forum.

The public only came to realise the danger they were facing once the government had locked the city. Collective panic and mounting fear of the unknown and unpredictable has made more Draconian controls justifiable and necessary in the public eye.

\section{Controling and monitoring individuals' movements}

As the spread of the virus escalated so have the containment measures. On 16 February the Hubei government issued a series of orders announcing that from the day onwards, except for those on official business, any cars seen in the street will be detained and any person seen in the street will be taken away. Wuhan netizens receive updates through social media of those wandering in the streets being taken to re-education camps (xuexi ban) located in local stadiums for 14 days and charged 150 RMB (approx. 33 AUD) per day for food and accommodation.

The lockdown of major cities has expedited the implementation of the government's e-zone system. E-Zone management, also known as grid management grid management (wangge hua guanli), is a nationwide digital social control system developed under Xi Jinping. It harks back to the baojia system widely used in Chinese ancient dynasties. Essentially the baojia system was a civil management 
system resembling that of the military, where a designated number of neighbouring families were grouped together as a unit managed by the unit administrator.

Under the e-zone system, each individual and family downloads a neighbourhood app which is able to locate the address of the individual and family and place them under a particular e-zone managed by an assigned zone administrator. The e-zone system makes each person and family's movement easily traceable. Residents and families in Wuhan have joined the system. They are governed by their respective ezone administrator, who is responsible for allocating food supply and checking on health condition of each family.

\section{Shaming those who don't conform}

In an effort to impose strict conformity to containment measures, shaming those who fail to take what are considered to be adequate measures to avoid getting infected and/or spreading the virus is at its maximum. Billboards relating to the coronavirus are awash with language such as "Those who do not disclose a fever are the class enemy hidden among the masses'. One video posted by the state-run Global Times newspaper shows a drone flying over villages in Inner Mongolia with a voiceover giving orders to an elderly woman, that "you shouldn't walk about without wearing a mask" and "you'd better go back home and don't forget to wash our hands ... we've been telling people to stay at home, but you still wander outside". An official video encouraging everyone to stay inside concludes with two rhyming lines: Sleeping in bed makes me glorified (wo shuijiao, wo guangrong); Walking about makes you a pest (ni luanpao, shi haichong).

In order to track down potential carriers of the virus, neighbours are encouraged to inform on one another (jubao) with a reward system. A number of netizens in different parts of China have independently informed me that their local districts have given an award of 1000 RMB (approx. 220 AUD) for dobbing one potential patient. As I have been informed by a Wuhan netizen, in his district, the reward 
system is more apprehensive: 1000 RMB (approx. 220 AUD) if the patient is a confirmed virus carrier, 500 RMB (approx. 110 AUD) if the patient is clear of virus. One video of a Wuhanese man, begging his neighbours to stop reporting him as his coughing was due to the burning chilli during cooking, went viral on social media.

\section{Information control}

The Central Committee of the CCP has taken systematic measures to ensure that the general public maintains a positive emotional response to the anti-pandemic war on all fronts. I have argued elsewhere that from ancient to contemporary times, ruling powers see views and voices diverting from political dogma as destructive as floods which are to be subject to control. Two ancient flood-control techniques, i.e. building high dykes to block and contain floods $(d u)$ and building water channels to direct water flow (shu), have long been used in Chinese governing to contain, mould and channel behaviour, beliefs and affect. In the face of war against virus, the CCP relies on full-blown use of the two techniques to control digital flow of information.

First, any information contradictory to the government line or questioning government capacity to deal with the virus crisis is deemed as malicious 'rumours' and blocked. Doctor Li Wenliang, who passed away from COVID-19 during his fight against the outbreak, warned his former colleagues on their exclusive wechat group in late December in respect to a mysterious virus that would become the coronavirus epidemic, was one of the eight doctors detained by police for 'spreading rumours' and 'seriously disrupting social order.' On 25 January 2020, the Wechat Security Centre issued 'Notice on Governing Rumours Relating to Novice Coronavirus' and announced harsh punishment for posting coronavirus 'rumours', quoting the PRC Criminal Law. Tens of thousands of wechat accounts were subsequently banned permanently.

At the same time, centrally coordinated effort has been made to direct and channel the flow of information. In mid-February, China's powerful Central Political and 
Legal Affairs Commission issued a notice demanding propaganda work to focus on social stability. According to the notice, propaganda work is to be strengthened to stimulate the positive energy of the society by producing 'warm news stories' that 'bring the audience to tears'. These stories should praise courage and selfless devotion of the exemplary judicial and public security officers and the Party-led volunteers. In doing so, the Central Political and Legal Affairs Commission calls upon an integration of political, legal, social, and media resources, fully utilising new media, such as weibo, wechat, Tik Tok, Kuaishou, and new communication tools such as images, animations, H5, mini videos and short videos. The notice demands establishment of columns and series of reports under such titles as 'Main Battlefield Connect', 'Frontline Diaries', 'Portrait of Anti-pandemic War', 'Anti-pandemic War Live' and 'War Heroes', encouraging peace volunteers, zone administrators, legal and police officers to make short videos and publish short texts, recording and displaying their work and sharing their personal feelings and touching stories. Helplessness, pain, anger, anxiety, panic are negative emotions that are not to be disclosed and discussed in public. Three popular independent citizen journalists, Chen Qiushi, Fang Bin and Li Zehua, who were reporting on the lives and suffering of individuals during the Wuhan lockdown, were arrested and at the time of publication remained missing.

\section{From Mao's "conflict readiness" to Xi's "bottom line" thinking}

'Readiness for conflict and readiness for famine' (beizhan beihuang) was the slogan introduced by Mao Zedong in 1964 in response to what the CCP perceived to be the imminent military threat posed upon China by the Soviet Union and the U.S. The slogan encapsulated the domestic and foreign affairs policy strategy that focused on stocking up food and clothing for the army and the people in preparation for an outbreak of war. Through the next half century, military confrontation may not have always been seen as the focal threat, risk consciousness (youhuan yishi) and conflict 
readiness, however, are embedded in the psyche of the CCP.

For example, higher education is regarded as 'the ideological battlefield' (yishi xingtai zhendi) against information flow that may threaten the foundational dogma of the CCP, as publishes on the Ministry of Education website, "The university students are receiving information from a multitude of channels and their mind is becoming active as a result. Under such circumstances how do we make Marxist theory dwell in the minds and hearts of the students, and what can universities do to create a pure spiritual home for the staff and students?'.

$\mathrm{Xi}$ Jinping's version of conflict readiness is expressed through his catchphrase 'bottom-line thinking' (dixian siwei). Bottom-line thinking, according to Xi Jinping, is the significant methodology and leadership style of the Party requiring each to be ready to tackle the worst-case scenario, and assess any risks, be it political, economic or ideological, which may pose threat upon the cause of the development of the Party and the nation for the New Era. In January 2019, key provincialministerial level government officials attended a four-day study session at the Central Party School on upholding the bottom-line thinking and focusing on preventing and mitigating major risks.

Coronavirus has given the CCP an opportunity to entrench and further institutionalise its authoritarian rule over Chinese society into the future. The EZone management system will accelerate the building of a 'see-through society' (touming shehui) where people's movements and everyday lives are closely monitored. On 15 December 2019 Cyberspace Administration of China issued a directive on ecological governance of information on cyberspace, effective from 1 March 2020. The heightened war-like social control mechanism has succeeded in mobilising the population against a common enemy. 'In this anti-pandemic war, each one of us is a soldier', says the mayor of Wuhan in his recent open letter to the Wuhan people. It, however, also turns Wuhan and other areas in the nation into a pressure cooker, where anger and agony are supressed. Once health crisis subsides and lockdown lifted, how will the CCP deal with the following complex social and 
economic catastrophes such as unemployment, food shortage, salary shortage and psychological trauma? After all, Wuhan is known for being a city of uprising. It was the Wuchang Uprising on 10 October 1911 against the ruling Qing dynasty that gave birth to the Republic of China.

The author wishes to thank Dr Anthony Spires for his helpful comments on the early ideas for this article.

Main image: BEIJING, CHINA - JANUARY 22: Chinese police officers wear protective masks at Beijing Station before the annual Spring Festival on January 22, 2020 in Beijing, China. (Photo by Kevin Frayer/Getty Images) 